\title{
PENERAPAN MODEL PEMBELAJARAN PEMETAAN PIKIRAN UNTUK MENINGKATKAN HASIL BELAJAR PKn SISWA KELAS IV
}

\author{
IB Surya Abadi, 1*, N L Uci Ragayanti², I N Murda ${ }^{3}$ \\ ${ }^{1}$ Universitas Pendidikan Ganesha \\ 2Universitas Pendidikan Ganesha \\ ${ }^{3}$ Universitas Pendidikan Ganesha
}

\begin{abstract}
Abstrak
Penelitian ini bertujuan untuk meningkatkan hasil belajar PKn setelah penerapan model pembelajaran Pemetaan Pikiran SD Negeri 3 Banyar Anyar. Subyek penelitian ini adalah siswa kelas IV SD Negeri 3 Banyar Anyar Tahun Pelajaran 2016/2017 yang bejumlah 18 orang siswa, Metode yang digunakan untuk mengumpulkan data hasil belajar adalah metode tes dengan alat pengumpulan data berupa tes hasil belajar yang dianalisis secara deskriptif kuantitatif. Hasil penelitian ini menunjukkan terjadi peningkatan persentase rata-rata hasil belajar siswa dari 70,55 \% dalam kategori sedang dan ketuntasan secara klasikal pada siklus I adalah $44,5 \%$ pada siklus I menjadi sebesar $80,6 \%$ dalam kategori tinggi pada siklus II dan ketuntasan secara klasikal pada siklus II sebesar 94,4\%. Berdasarkan analisis data dan pembahasan dapat disimpulkan bahwa penerapan model pembelajaran pemetaan pikiran dapat dijadikan salah satu alternatif dalam mengajar untuk meningkatkan hasil belajar siswa dalam mata pelajaran PKn.
\end{abstract}

\section{Pendahuluan}

Keywords:

pembelajaran pemetaan pikiran, hasil belajar

Kualitas Sumber Daya Manusia (SDM) yang baik akan mendukung kemajuan suatu bangsa. Pendidikan merupakan komponen penting untuk mewujudkan terbentuknya SDM yang berkualitas. Seperti yang tercantum dalam UU No. 20/2003 tentang Sistem Pendidikan Nasional. Bab I Pasal 1 ayat 1 disebutkan bahwa pendidikan adalah usaha sadar dan terencana untuk mewujudkan suasana belajar dan proses belajar agar peserta didik secara aktif mengembangkan potensi dirinya agar memiliki kekuatan spiritual keagamaan, pengendalian diri, kepribadian, kecerdasan, akhlak mulia, serta keterampilan yang diperlukan dirinya, masyarakat, bangsa, dan negara. Berdasarkan pengertian tersebut dapat diartikan bahwa melalui pendidikan, peserta didik dapat mengembangkan kemampuan atau potensi yang dimiliki untuk melahirkan pribadi yang beriman dan bertaqwa, memiliki kecerdasan, serta keterampilan yang memadai (Ilyas, 2008).

Usaha yang dapat dilakukan untuk meningkatkan mutu pendidikan, terutama di Indonesia adalah melalui pengoptimalan pelaksanaan pembelajaran baik di sekolah formal, informal, maupun nonformal. Kerjasama berbagai pihak sangat diperlukan dalam rangka tercapainya tujuan pembelajaran yang telah ditetapkan. Penguasaan kompetensi pada aspek sikap, pengetahuan, dan keterampilan menjadi pembuktian keberhasilan proses pembelajaran. Sikap, pengetahuan, dan keterampilan yang diperoleh siswa melalui proses belajar, nantinya akan sangat berguna sebagai bekal hidupnya dalam kehidupan berbangsa dan bernegara.

Pada era globalisasi seperti sekarang ini, masyarakat dituntut untuk memiliki karakter dan jiwa kebangsaan yang tinggi dalam menjalani kehidupan berbangsa dan bernegara. Pengembangan karakter dan jiwa kebangsaan harus dimulai sejak dini mulai dari usia anak sekolah (Wijana, 2015). Pengembangan tersebut bisa diintegrasikan pada setiap pembelajaran di sekolah. Pembelajaran yang utama yang menjadi dasar pengembangan karakter dan jiwa kebangsaan di sekolah yaitu pada pembelajaran Pendidikan Kewarganegaraan (PKn). Pendidikan Kewarganegaraan merupakan mata pelajaran yang sangat penting yang berfungsi untuk membentuk karakter siswa yang berjiwa kebangsaan. Menurut Merphin Panjaitan (dalam Murda, 2014), pendidikan kewarganegaraan adalah pendidikan demokrasi yang bertujuan untuk mendidik generasi muda untuk menjadi warga negara yang demokrasi dan partisipatif melalui suatu

\footnotetext{
* Corresponding author.

E-mail Addresses: suryaabadi31@yahoo.co.id (IB Surya Abadi), uci_ragayanti@yahoo.com(N L Uci Ragayanti ${ }^{1}$ nyomanmurda@yahoo.co.id( $(I$

$N$ Murda $^{2}$ )
} 
pendidikan yang dialogial. Sementara Soedijarto (dalam Murda, 2014) mengartikan pendidikan kewarganegaraan sebagai pendidikan politik yang bertujuan untuk membantu peserta didik menjadi warga negara yang secara politik dewasa dan ikut serta membangun sistem politik yang demokratis. Selanjutnya Bakry (2011) dan Azyumardi (2008) mengemukakan PKn adalah usaha sadar untuk menyiapkan siswa dalam mengembangkan kecintaan, kesetiaan, keberanian untuk berkorban membela bangsa dan tanah air Indonesia. PKn adalah pendidikan yang cakupannya lebih luas dari pendidikan demokrasi dan pendidikan HAM karena mencakup kajian dan pembahasan tentang banyak hal. Kementrian Pendidikan Nasional (2011), mengemukakan Mata Pelajaran PKn merupakan mata pelajaran yang memfokuskan pada pembentukan warga negara yang memahami dan mampu melaksanakan hakhak dan kewajibannya untuk menjadi warga negara Indonesia yang cerdas, terampil, dan berkarakter yang diamanatkan oleh Pancasila dan UUD 1945.

Mengingat sangat pentingnya peran pembelajaran PKn dalam upaya pengembangan masyarakat yang berkarakter dan memiliki jiwa kebangsaan yang tinggi maka diperlukan proses pembelajaran yang benar-benar mampu mengarahkan siswa yang memiliki karakter dan jiwa kebangsaan. Hal tersebut tentunya harus melalui proses pembelajaran PKn yang menarik dan membuat siswa antusias bersemangat mengembangkan karakter dan jiwa kebangsaannya serta kemampuan yang dimilikinya. Peningkatan hal tersebut akan tercermin dari hasil belajar yang dicapai oleh siswa. Sudjana (2006) dan Widiana (2014) mengemukakan bahwa hasil belajar adalah kemampuan-kemampuan yang dimiliki siswa setelah ia menerima pengalaman belajarnya. Gagne dalam Purwanto (2011) mengatakan hasil belajar adalah terbentuknya konsep, yaitu ketegori yang kita berikan pada stimulus yang ada di lingkungan, yang menyediakan skema yang terorganisasi untuk mengasimilasi stimulus-stimulus baru dan menentukan hubungan di dalam dan diantara kategori-kategori. Demikian juga Suprijono dalam Thobroni (2011), mengatakan hasil belajar adalah pola-pola perbuatan, nilai-nilai, pengertian-pengertian, sikap-sikap, apresiasi, dan keterampilan. Muhammad Ali (dalam Agung, 2014) menyatakan bahwa faktor-faktor yang mempengaruhi hasil belajar adalah faktor guru, siswa, kurikulum dan lingkungan. Keempat faktor tersebut dapat dijelaskan sebagai berikut:Faktor guru, Faktor siswa, Faktor kurikulum, Faktor lingkungan. Menurut Bloom (dalam Sudjana, 2010) membagi hasil belajar menjadi tiga ranah yaitu kognitif, afektif, dan psikomotor. Ranah kognitif berkenaan dengan hasil belajar intelektual, ranah afektif berkenaan dengan sikap, ranah psikomotorik berkenaan dengan hasil belajar keterampilan dan kemampuan bertindak. Belajar dapat mengubah tingkah laku seseorang.

Pada kenyataannya di berbagai sekolah ditemukan bahwa pembelajaran PKn adalah pembelajaran yang cenderung membosankan bagi siswa sehingga menjadi kendala dalam mencapai tujuan pembelajaran PKn. Hasil observasi di SD Negeri 3 Banjar Anyar menemukan bahwa siswa cenderung meremehkan mata pelajaran tersebut dan sering menganggap bahwa mata pelajaran PKn merupakan mata pelajaran yang tidak penting. Sehingga hasil belajar yang diperoleh siswa pada pelajaran PKn belum sesuai dengan tujuan pembelajaran yang diharapkan. Padahal sudah sangat jelas bahwa pembelajaran PKn merupakan pelajaran sangat penting yang akan berpengaruh bagi kelangsungan hidup untuk kedepannya nanti.

Dalam hasil observasi juga ditemukan beberapa permasalahan lainya, seperti kurangnya pemahaman siswa terhadap konsep pembelajaran PKn sehingga menjadi pelajaran yang kurang menyenangkan dan memotivasi, rendahnya minat dan kreativitas siswa untuk belajar, kurangnya pemanfaatan fasilitas yang mendukung kegiatan pembelajaran, dan Guru kelas IV belum memiliki pengalaman yang inovatif di kelas. Kegiatan pembelajaran seperti itu yang cenderung menggunakan metode ceramah dalam penyampaian materi PKn atau lebih berpusat pada guru berakibat pada rendahnya hasil belajar PKn siswa kelas IV. Hal ini bisa dilihat dari nilai ulangan harian yang memenuhi KKM yaitu 75 hanya $35 \%$ dari 18 siswa yang memperoleh ketuntasan belajar. Hal tersebut memperlihatkan bahwa masih banyak siswa yang memiliki hasil belajar berada di bawah KKM yang telah ditentukan sekolah.

Untuk mengatasi hal tersebut di atas, maka diperlukan inovasi guru dalam menggunakan salah satu model pembelajaran alternatif yang dapat menarik minat siswa untuk belajar sehingga mampu mencapai tujuan pembelajaran dan tujuan pendidikan kewarganegaraan secara optimal. Inovasi yang dilakukan guru diharapkan mampu meningkatkan hasil belajar siswa. Salah satu inovasi yang harus dilakukan guru adalah memilih dan mengembangkan metode mengajar yang sesuai dengan materi yang diajarkan dan karakteristik siswa sehingga pembelajaran yang berlangsung menjadi lebih efektif dan tidak membosankan (Mediatati, 2017). Salah satu model pembelajaran yang dapat mengatasi permasalahan yang ditemukan tersebut adalah melalui penerapan model pembelajaran pemetaan pikiran (mind mapping).

Alamsyah (2009) berpendapat bahwa sistem peta pikiran atau mind mapping adalah suatu teknik visual yang dapat menyelaraskan proses belajar dengan cara kerja alami otak. Buzan (2004) 
mengemukakan bahwa mind mapping adalah cara mudah menggali informasi dari dalam otak yang merupakan cara baru untuk belajar dan berlatih yang cepat dan ampuh dengan membuat catatan yang tidak membosankan untuk mendapatkan ide baru dan merencanakan proyek (Redjeki , 2007). Dijelaskan juga oleh Buzan (2005) mind mapping adalah bentuk istimewa pencatatan dan perencanaan yang bekerja selaras dengan otak untuk memudahkan mengingat. Mind mapping menggunakaan warna dengan gambar-gambar untuk membantu membangunkan imajinasi (Purwoko, 2007).

Menurut Anisyah dkk, 2012 mengatakan bahwa mind mapping merupakan suatu teknik visual dalam bentuk istimewa pencatatan dan perencanaan, alternatif pikiran keseluruhan otak yang dapat menyelaraskan proses belajar dan dapat digunakan untuk menyimpan informasi. Langkah-langkah pembelajaran model mind mapping menurut Buzan (1993) terdapat 4 langkah yang harus dilakukan yaitu: (1) Overview: TINJAUAN menyeluruh terhadap suatu topik pada saat proses pembelajaran baru dimulai; (2) Preview: Tinjauan awal yang merupakan lanjutan dari overviewP; (3) Inview: Tinjauan mendalam yang merupakan inti dari suatu proses pembelajaran; (4) Review: Tinjauan ulang dilakukan menjelang berakhirnya jam pelajaran dan berupa ringkasan dari yang bahan telah diajarkan (Yoga, 2007). Sementara itu untuk mengaplikasikan mind mapping dalam kegiatan pembelajaran di sekolah, ada 4 tahap yang harus dilakukan yaitu: (1) Tahap persiapan; (2) Tahap pendahuluan; (3) Tahap transisi; dan (4) Tahap implementasi; (Yoga, 2007).

Tampubolon (2011) mengatakan model pembelajaran kooperatif berbantuan mind mapping sangat baik digunakan untuk pengetahuan awal siswa atau untuk menemukan alternatif jawaban. Selanjutnya Wycoff dalam Hernowo (2003), mengatakan bahwa mind mapping memiliki efek yang hampir tidak masuk akal dapat membuka jalan ke seluruh otak, mendorong timbulnya kreativitas, mendobrak penghalang bagi para penulis, dan menyediakan mekanisme urun-rembuk yang efektif. Redjeki (2007), mengungkapkan mind mapping adalah: (1) cara mudah menggali informasi dari dalam dan dari luar otak, (2) cara baru untuk belajar dan berlatih yang cepat dan ampuh, (3) cara membuat catatan yang tidak membosankan, dan (4) cara terbaik untuk mendapatkan ide baru dan merencanakan proyek. Konsep ini didasarkan pada cara kerja otak kita dalam menyimpan informasi.

Tony dan Bary Buzan (2004) menyatakan bahwa peta pemikiran merupakan teknik yang paling baik dalam membantu proses berpikir otak secara teratur karena menggunakan teknik grafis yang berasal dari pemikiran manusia yang bermanfaat untuk menyediakan kunci-kunci universal sehingga membuka potensi otak. Peta pikiran adalah teknis meringkas bahan yang akan dipelajari dan memproyeksikan masalah yang dihadapi kedalam bentuk peta atau teknik grafik sehingga lebih mudah memahaminya. Elemen-elemen yang dimiliki oleh setiap mind mapping (Alamsyah, 2009),: Pusat Peta pikiran, merupakan ide atau gagasan utama. Pusat peta pikiran dapat dituliskan dalam bentuk teks ataupun suatu gambar. Tulis atau gambarkan pusat peta pikiran ditengah-tengah kertas. Jadi, ia benar-benar merupakan topik sentral dari apa yang divisualkan. Dengan menuliskan pertama kali, pikiran akan fokus pada pokok permasalahan. Cabang Utama, cabang tingkat pertama yang langsung memancar dari pusat peta pikiran. Cabang utama ini juga dapat disebut Basic Ordering Ideas (BOI), ada juga yang menyebutnya main branch. Masing-masing cabang utama diberi simbol sehingga menjadi sangat menarik. Cabang, Cabang merupakan pancaran dari cabang utama yang dapat dituliskan ke segala arah. Diusahakan dalam membuat cabang garis yang digunakan meliuk bukan sekedar garis lurus. Dalam pemberian warna, sebaiknya warna cabang sama dengan warna cabang utamanya. Kata, Setiap berisi satu kata kunci (keyword). Kata kunci tersebut ditulis di atas cabang. Semakin keluar semakin kecil hurufnya. Gambar, Tidak ada aturan baku tentang penggunaan gambar. Dapat menggunakan gambar-gambar yang disukai oleh siswa. Usahakan gambar tersebut merupakan visualisasi dari kata kunci pada cabang.

Buzan (2004) menyampaikan tahap-tahap penting yang harus diperhatikan dalam membuat peta pikiran (mind mapping) adalah sebagai berikut mulailah dari bagian tengah kertas kosong yang sisi panjangnya diletakkan mendatar, karena memulai dari tengah memberi kebebasan kepada otak untuk menyebar ke segala arah dan untuk mengungkapkan dirinya dengan lebih bebas dan alami. Gunakan gambar atau foto untuk ide sentral, karena sebuah gambar bermakna seribu kata dan membantu siswa menggunakan imajinasi. Sebuah gambar sentral akan lebih menarik, tetap berfokus, membantu berkonsentrasi, dan dapat mengaktifkan otak.Gunakan warna, karena bagi otak warna sama menariknya dengan gambar. Warna membuat mind mapping lebih hidup, menambah energi kepada pemikiran kreatif dan menyenangkan. Hubungkan cabang-cabang utama ke gambar pusat dan hubungkan cabang-cabang tingkat dua dan tiga ke tingkat satu dan dua, dan seterusnya, karena otak bekerja menurut asosiasi. Otak senang mengaitkan dua (atau tiga, atau empat) hal sekaligus. Bila dihubungkan cabang-cabang, akan lebih mudah mengerti dan mengingat. Buatlah garis hubung yang melengkung, bukan garis yang lurus, karena garis lurus akan membosankan anak. Cabang-cabang yang melengkung dan organis, seperti cabangcabang pohon, jauh lebih menarik bagi mata. Gunakan satu kata kunci untuk setiap garis, karena kata kunci tunggal memberi lebih banyak daya dan fleksibilitas kepada mind mapping. Gunakan gambar, 
karena setiap gambar bermakna seribu kata. Dalam proses pembuatan pemetaan pikiran menentukan central topik atau ide pokok dari sebuah mind mapping. Membuat ide dasar yang teratur atau biasa disebut dengan BOIS untuk central topik yang dipilih yang diletakkan ditengah- tengah kertas. Melengkapi setiap ide dasar mengunakan cabang utama yang kemudian akan dihubungkan dengan cabang- cabang yang melengkapi cabang utama yang berisi data-data yang mendukung central topik. Melengkapi setiap cabang dengan menggunakan gambar, simbol, atau kode yang disukai siswa untuk mengaitkan setiap cabang yang saling terhubung sehingga memudahkan siswa untuk mengingat dan memahami materi yang telah dibuat menjadi sebuah peta pikiran (mind mapping).

Beberapa kelebihan dari pembelajaran dengan model pembelajaran pemetaan pikiran (mind mapping) (Buzan, 2004) adalah meningkatkan hubungan antar individu karena siswa berpeluang sama untuk terlibat secara aktif, interaksi yang lebih banyak, saling berbagi tanggung jawab, dan saling mengisi, memberikan dukungan pada interaksi sosial, karena akan tertanam sikap saling menghargai pendapat teman yang merupakan cerminan dari sikap ilmiah, meningkatkan ketekunan, ketabahan, dan keuletan dalam mengerjakan tugas-tugas, memupuk rasa percaya diri dan meningkatkan kualitas konsep diri masing-masing siswa, meningkatakan produktivitas akademik, memperluas perspektif siswa, merangsang kemampuan berpikir siswa, meluruskan pandangan yang dibawa siswa sebelumnya masih bersifat tidak ilmiah, membentuk sikap siswa untuk tidak menjadi egosentris.

Penerapan model pembelajaran pemetaan pikiran (mind mapping) diharapkan dapat memotivasi kreatifitas siswa karena siswa ditantang untuk membuat peta pikiran atau peta konsep dengan kreatifitas sendiri sehingga siswa dengan mudah dapat memahami setiap materi yang diajarkan sehingga berdampak pada peningkatan hasil belajar siswa.

\section{Metode}

Penelitian ini dilakukan di SD Negeri 3 Banyar Anyar pada semester I Tahun Pelajaran 2016/2017. Obyek penelitian dalam kegiatan ini adalah penerapan model pembelajaran Pemetaan Pikiran (mind mapping). Subyek penelitian dalam kegiatan ini adalah siswa kelas IV SD Negeri 3 Banyar Anyar dengan jumlah siswa 18 orang yang terdiri dari 11 orang laki-laki dan 7 orang perempuan. Jenis penelitian yang dilaksanakan adalah penelitian tindakan kelas (Classroom Action Reseach) (Paizaluddin dan Ermalinda (2013)). Berdasarkan analisis terhadap permasalahan yang ada, pelaksanaan penelitian ini direncanakan terdiri dari 2 siklus. Dalam setiap siklus terdapat empat tahapan yang harus dilaksanakan, meliputi perencanaan, pelaksanaan, pengamatan, serta refleksi. Jila hasil yang dicapai telah memenuhi kriteria keberhasilan yang ditetapkan, maka penelitian dihentikan. Namun, jika belum mencapai hasil yang diharapkan maka penelitian tindakan kelas dilanjutkan ke siklus berikutnya.

Metode pengumpulan data yang digunakan dalam penelitin ini adalah metode tes, yaitu cara memperoleh data yang berbentuk suatu tugas yang harus dikerjakan oleh seseorang atau kelompok orang yang dites (testee), dan dari tes tersebut dapat menghasilkan suatu data berupa skor (Agung, 2014; Arikunto, 20101). Dalam penelitian ini metode tes digunakan untuk mengumpulkan data tentang hasil belajar siswa dalam proses pembelajaran PKn. Tes ini dimaksudkan untuk mengevaluasi tingkat pemahaman konsep siswa terhadap materi yang dipelajari selama setiap satu siklus pembelajaran. Untuk mengetahui hasil belajar PKn pada siswa kelas IV digunakan instrumen berupa tes obyektif yang berjumlah 20 butir soal dengan jalan memilih salah satu atau lebih diantara beberapa kemungkinan jawaban yang telah dipasangkan pada masing-masing ítem Anas Sudijono (2012).

Untuk mengetahui persentase hasil belajar siswa, rata-rata skor yang telah diperoleh dengan menggunakan rumus dapat dikonversikan ke dalam tabel prosentase hasil belajar PKn.

Tabel 1 Konversi Hasil Belajar PKn

\begin{tabular}{cc}
\hline Persentase Penguasaan & Kategori \\
\hline $85-100$ & Sangat tinggi \\
$70-84$ & Tinggi \\
$55-69$ & Sedang \\
$40-54$ & Rendah \\
$0-39$ & Sangat Rendah \\
\hline
\end{tabular}

Adapun indikator keberhasilan penelitian ini adalah hasil belajar siswa pada mata pelajaran PKn mencapai kategori tinggi dengan ketuntasan belajar siswa mencapai 75\%, artinya 75\% siswa dari jumlah keseluruhan yang memperoleh nilai diatas KKM yang ditetapkan. 


\section{Hasil dan Pembahasan}

Setelah pelaksanaan tindakan pembelajaran siklus I dengan menerapkan pembelajaran pemetaan pikiran (Mind Mapping) hasil belajar PKn siswa belum sepenuhnya berhasil. Data hasil belajar siswa pada siklus I menunjukkan persentase rata-rata hasil belajar mencapai 70,55\% dan ketuntasan secara klasikal pada siklus I adalah 44,5\%. Persentase rata-rata hasil belajar siswa jika dikonversikan pada Tabel Kreteria Penilaian Acuan Patokan (PAP) berada pada rentang 65\% - 79\% dengan kategori sedang. Hal tersebut menunjukkan bahwa hasil persentase rata-rata hasil belajar siswa pada siklus I belum memenuhi kriteria, sehingga dapat dikatakan pelajaran PKn pada siklus I belum tuntas maka perlu diadakan refleksi dalam menentukan perbaikan untuk melanjutkan penelitian pada siklus ke II.

Berdasarkan paparan di atas, maka pada pelaksanaan tindakan pembelajaran pada siklus berikutnya perlu dilakukan perbaikan sehingga hasil belajar siswa akan meningkat dan mencapai kriteria yang diharapkan. Selama proses tindakan pembelajaran pada siklus I terdapat beberapa kendala yang timbul yang harus ditindak lanjuti, adapun kendala-kendala yang timbul pada proses pembelajaran siklus I yaitu: kurangnya waktu yang diperlukan untuk mempersiapkan metode yang digunakan dalam penelitian, kurangnya fasilitas, biaya dan alat yang digunakan untuk mendukung terlaksananya penelitian, siswa belum terbiasa dalam menggunakan model pembelajaran mind mapping. Kurangnya motivasi siswa untuk mengajukan pertanyaan. Saat diskusi berlangsung sering terjadi dominasi yang mengakibatkan hanya satu atau beberapa siswa yang aktif, sehingga mengakibatkan siswa yang lain menjadi pasif.

Berdasarkan hasil refleksi tersebut, maka untuk menindaklanjuti permasalahan yang terdapat pada siklus I maka hal-hal yang dilakukan untuk meningkatkan hasil belajar PKn sebagai berikut, Guru mempersiapkan lebih awal metode serta alat yang akan digunakan untuk mendukung terlaksananya penelitian. Menyamakan persepsi kembali mengenai pelaksanaan pembelajaran dengan menerapkan model pembelajaran mind mapping kepada siswa agar siswa bisa lebih tertarik untuk mengikuti pelajaran. Memberikan motivasi dan kesempatan kepada siswa yang kurang untuk mengemukakan pendapatnya, sehingga ia merasa diperhatikan. Memberikan kesempatan kepada seluruh siswa untuk aktiv dalam setiap pembelajaran untuk menghindari adanya dominasi oleh beberapa siswa saja.

Pelaksanaan siklus II menggunakan proses pelaksanaan yang sama dengan siklus I, yaitu dilaksanakan dalam 4 kali pertemuan, 3 kali pertemuan untuk pelaksanaan kegiatan pembelajaran dan 1 kali pertemuan untuk pelaksanaan evaluasi hasil belajar. Data yang diperoleh dari hasil belajar siswa pada siklus II sebesar 94,4\% yang berada pada rentang 80\%-89\% dengan kriteria tinggi dan ketuntasan secara klasikal pada siklus II sebesar 94,4\%. Berdasarkan data tersebut, hasil belajar siswa sudah memenuhi kriteria yang diharapkan yaitu berada pada kategori tinggi.

Berdasarkan temuan pada siklus I dan II, terdapat peningkatan hasil belajar sebesar 10,05\%. Peningkatan ini terjadi karena, meningkatkan hubungan antar individu, karena siswa berpeluang sama untuk terlibat secara aktif, memberikan dukungan pada interaksi sosial, karena akan tertanam sikap saling menghargai pendapat teman yang merupakan cerminan dari sikap ilmiah, meningkatkan ketekunan, ketabahan, dan keuletan dalam mengerjakan tugas-tugas, memupuk rasa percaya diri dan meningkatkan kualitas konsep diri masing-masing siswa. meningkatakan produktivitas akademik. memperluas perspektif siswa, merangsang kemampuan berpikir siswa, meluruskan pandangan yang dibawa siswa sebelumnya masih bersifat tidak ilmiah, membentuk sikap siswa untuk tidak menjadi egosentris.

Hasil setelah diberikan tindakan pada siklus I persentase rata-rata skor hasil belajar siswa baru mencapai 69,62\%. Setelah pelaksanaan tindakan pada siklus terjadi peningkatan pada hasil belajar PKn yaitu persentase rata-rata skor $80,27 \%$ dengan kategori tinggi. Hasil belajar pada siklus I dan siklus II disajikan dalam grafik hasil belajar di bawah ini
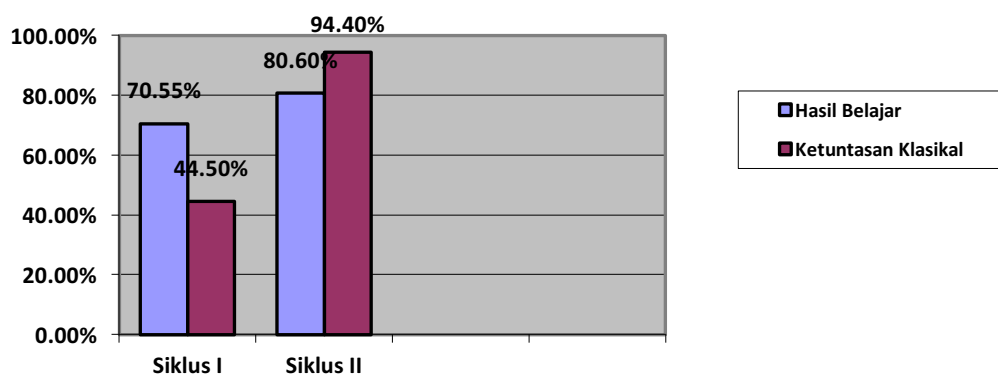

Grafik 1 Persentase Hasil Belajar Siswa Kelas IV SD Nomor 3 Sempidi dalam Mata Pelajaran PKn Pada Siklus I dan Siklus I 
Berdasarkan data yang diperoleh pada siklus II menunjukkan bahwa indikator keberhasilan yang diharapkan dalam penelitian ini sudah terpenuhi. Sehingga terjadi peningkatan persentase rata-rata skor hasil belajar dari siklus I ke siklus II sebesar 10,65\%. Hasil penelitian yang diperoleh ini menguatkan temuan penelitian yang telah dilakukan sebelumnya. Penelitian yang dilaksanakan oleh Santihani dengan hasil penelitian ini sama- sama terdapat peningkatan yang signifikan dalam hasil penelitiannya. Hanya saja penelitian ini lebih terfokus pada penulisan surat pribadi. Maka dapat dikemukakan bahwa temuan ini (2017) memperkuat simpulan Santihani (2016). Gusti Ayu Mirah Wulandari (2016) juga memperoleh hasil yang sejalan yaitu penerapan pendekatan saintifik melalui Mind Mapping mampu meningkatkan penguasaan kompetensi keterampilan menulis Bahasa Indonesia siswa kelas IVA SD negeri 29 pemecutan tahun ajaran 2015/2016. Keterampilan menulis surat pribadi siswa Kelas IIIA SDN 1 Sumerta dapat ditingkatkan melalui penerapan metode mind mapping (Dwitha, Evayanti \& Made Sumantri, 2017)

Pemetaan pikiran (mind mapping) adalah cara yang sangat baik untuk menghasilkan dan menata gagasan sebelum menulis (Wycoff, 2005). Melalui mind mapping, siswa mampu memudahkan siswa dalam memahami pelajaran dan menciptakan pembelajaran yang menyenangkan, nyaman, dan bermakna. Menurut Tony Buzan (2004), mind map adalah cara mencatat yang kreatif, efektif, dan secara harfiah akan "memetakan" pikiran-pikiran kita. Mind map adalah diagram yang digunakan untuk menggambarkan sebuat tema, ide, atau gagasan utama dalam materi pelajaran (Rostikawati, 2008; Andri Saleh, 2009). Jadi mind mapping ini dibuat oleh guru untuk menyampaikan materi pelajaran dan digunakan juga oleh siswa untuk pencatatan materi pelajaran ataupun hasil diskusi kelompok.

Hal ini dapat disimpulkan bahwa melalui penerapan model pembelajaran pemetaan pikiran (Mind Mapping) mampu memudahkan siswa dalam memahami pelajaran dan menciptakan pembelajaran yang menyenangkan, nyaman, dan bermakna sehingga berdampak pada peningkatan hasil belajar PKn siswa kelas IV SD Negeri 3 Banyar Anyar tahun pelajaran 2016/2017. Hal ini dikarenakan Mind Mapping membuat materi pelajaran terpola secara visual dan grafis yang akhirnya dapat membantu merekam, memperkuat, dan mengingat kembali informasi yang telah dipelajari

\section{Simpulan dan Saran}

Berdasarkan pembahasan hasil penelitian, maka dapat disimpulkan bahwa penerapan model pembelajaran pemetaan pikiran (Mind Mapping) dapat meningkatkan hasil belajar PKn siswa kelas IV SD Negeri 3 Banyar Anyar Tahun Pelajaran 2016/2017. Hal ini ditunjukkan dengan hasil penelitian yang diperoleh yaitu persentase rata-rata skor pada siklus I 68,05\% yang berada pada kriteria Sedang dan meningkat lagi pada siklus II menjadi $80,27 \%$ yang berada pada kriteria Tinggi. Sehingga terjadi peningkatan persentase rata-rata skor dari siklus I ke siklus II sebesar 10,65\%.

Berdasarkan hasil penelitian ini disarankan: siswa hendaknya dalam mengikuti proses pembelajaran siswa lebih aktif dan fokus agar siswa dapat memahami penerapan model pembelajaran pemetaan pikiran (Mind Mapping) yang diberikan oleh guru, karena model pembelajaran ini sangat tepat diterapkan untuk dapat meningkatkan hasil belajar siswa. Guru diharapkan kepada guru agar dapat menerapkan model pembelajaran pemetaan pikiran (Mind Mapping) untuk meningkatkan kualitas proses pembelajaran di kelas, dan dapat menjadi salah satu alternatif dalam melaksanakan pembelajaran yang inovatif sehingga suasana kegiatan pembelajaran menjadi lebih menyenangkan. Sekolah hendaknya menggunakan hasil penelitian ini sebagai sumber informasi dalam upaya merancang program pembelajaran untuk meningkatkan kualitas pendidikan di sekolah. Peneliti lain hendaknya hasil penelitian ini dijadikan sebagai acuan penelitian yang dilakukan dandisarankan saat melakukan penelitian yang sejenis untuk mengetahui efektivitas model pembelajaran pemetaan pikiran (mind mapping).

\section{Daftar Pustaka}

Agung, A.A Gede. (2014). Metodologi Penelitian Pendidikan. Malang: Aditya Media Publishing

Alamsyah, M. (2009). Kiat Jitu Meningkatkan Prestasi dengan Mind Mapping. Jogjakarta: Mitra Pelajar.

Anisyah,N., (2012),Pengaruh strategi pembelajaran inkuiri dengan metode demonstrasi terhadap hasil belajar siswa pada pokok bahasan koloid kelas XI IPA SMA Negeri 1 Seisuka tahun pembelajaran 2011/2012., Skripsi, FMIPA, Unimed, Medan

Arikunto. Suharsimi, (2010). Dasar-Dasar Evaluasi Pendidikan. Jakarta : Bumi Aksara

Azyumardi, Azra. (2011). Belajar dan Pembelajaran. Yogyakarta: Ar Ruzz Media 
Buzan, T. (1993). Buku Pintar Mind Map untuk Anak Agar Anak Mudah Menghafal dan Berikonsentrasi. Terj. Purwoko, S. Jakarta: PT Gramedia Pustaika Utama (Buku asli diterbitkan 2005).

Buzan, T. (2004). Mind Map untuk Meningkatkan KIreativitas. Terj. Suryaputra, E. Jakarta: PT Gramedia Pustakia Utama. (Buku asli diterbitkan 2001).

Buzan, T. (2007). Buku Pintar Mind Map untuk Anak Agar Anak menjadi Pintar di Sekolah. Terj. Redjeki, S. Jakarta: PT Gramedia Pustaka Utama. (Buku asli diterbitkan 2003).

Daniel Winantara, IW., I Nyoman Laba Jayanta. (2017). Penerapan Model Pembelajaran TPS Untuk Meningkatkan Hasil Belajar IPA Siswa Kelas V SD No 1 Mengwitani. Jurnal Ilmiah Sekolah Dasar. Vol. 1 No. 1.

Dwitha, Evayanti \& Made Sumantri. (2017). Penerapan Metode Mind Mapping Untuk Meningkatkan Keterampilan Menulis Surat Pribadi Siswa Kelas IIIA. Jurnal Ilmiah Sekolah Dasar. Vol.1 (1) pp. 42-50.

Febrian Kurniasari, Elisabet., Eunice Widyanti Setyaningtyas. (2017). Peningkatan Hasil Belajar IPS Melalui Penerapan Model Pembelajaran Kooperatif Tipe Think Pair and Share (TPS) dengan Teknik Gallery Walk. Journal of Education Research and Evaluation. Vol. 1 No. 2.

Hernowo. 2003. Quantum Reading. Bandung: Mizan Learning Center.

Juniati, Ni Wayan., I Wayan Widiana. (2017). Penerapan Model Pembelajaran Inkuiri Untuk Meningkatkan Hasil Belajar IPA. Jurnal Ilmiah Sekolah Dasar. Vol. 1 No. 1.

Kementerian Pendidikan Nasional. 2011. Standar Kompetensi dan Kompetensi Dasar. Badan Standar Pendidikan Nasional.

Mediatati, Nani. (2017). Meningkatkan Hasil Belajar PPKn Menggunakan Model Pembelajaran Examples Non Examples pada Siswa Kelas VIIIE SMP Negeri 6 Salatiga. Journal of Education Research and Evaluation. Vol. 1 No. 2.

Murda, Nyoman, dkk. 2014. Pendidikan Kewarganegaraan . Singaraja : Undiksha

Mustika, Pande Wayan., I Made Sutajaya. (2016). Ergonomi Dalam Pembelajaran Menunjang Profesionalisme Guru Di Era Global. Jurnal Pendidikan Indonesia. Vol. 5 No. 1.

Noor Bakry, Ms. 2011.Pendidikan Kewarganegaraan. Yogyakarta: Pustaka Belajar.

Paizaluddin dan Ermalinda. 2013. Penelitian Tindakan Kelas. Bandung : Alfabeta

Purwanto. 2011. Evaluasi Hasil Belajar. Yogyakarta: Pustaka Pelajar.

Purwoko. T. 2007. Model Pembelajaran. Bumi Aksara. Jakarta

Putrayasa, Ida Bagus. (2015). Pembelajaran Menulis Paragraf Deskripsi Berbasis Mind Mapping Pada Siswa Kelas Vii Smp Laboratorium Undiksha. Jurnal Pendidikan Indonesia. Vol. 2 No. 2.

Ragita Adiputra, Ida Bagus. (2012). Analisis Butir Soal Tes Ulangan Akhir Semester IPS Terpadu Buatan MGMP IPS Kabupaten Gianyar Kelas VII Semester 1. Jurnal Pendidikan Indonesia. Vol. 1 No. 1.

Redjeki, Sri.2007. Buku Pintar Mind Mapping. Jakarta: PT. Gramedia Pustaka Utama.

------, Sri. 2007. “Analisis Pengaruh Struktur Kepemilikan, Ukuran Perusahaan dan Rasio Perputaran Persediaan Terhadap Pemilihan Metode Persediaan pada Perusahaan Manufaktur Go Public di BEJ". Skripsi Tidak Dipublikasikan, Fakultas Ekononomi, Universitas Semarang.

Rostikawati, R. Teti. 2008. Mind Mapping dalam Metode Quantum Learning Pengaruhnya Terhadap Prestasi Belajar dan Kreatifitas Siswa. Fakultas Keguruan dan Ilmu Pendidikan - Universitas Pakuan. (Online). (http://etalaseilmu.wordpress.com/2009/10/02/mind-mapping-metodequantum-learning/. Dikunjungi tanggal 19 Juli 2012)

Saleh, Andri. (2009). Kreatif Mengajar Dengan Mind Map. Bogor: CV Regina

Septina Witari Dewi, Gusti Ayu Made., Ni Ketut Suarni, I Wayan Widiana. (2014). Pengaruh Model Pembelajaran Tandur Terhadap Hasil Belajar IPA Ditinjau Dari Minat Belajar Siswa. Mimbar PGSD. Vol. 2 No. 1.

Sudijono, Anas. 2012. Pengantar Evaluasi Pendidikan. Jakarta :PT Raja Grafindo Persada 
Sudjana, Nana. 2006. Penilaian Hasil Proses Belajar Mengajar. Bandung. Remaja Rosdakarya.

Tampubolon, Saur. 2011. Bimbingan Penulisan Karya Ilmiah, PTK, Skripsi, dan KTI. Bogor.

Thobroni, Muhammad \& Azra Azyumardi. 2011. Belajar dan Pembelajaran. Yogyakarta: Ar Ruzz Media

Tonny and Barry,Buzan. 2004. Memahami Peta Pikiran : The Mind Map Book. Batam: Interaksa

Tonny, Buzan . 2004. Mind Map : Untuk Meningkatkan Kreativitas. Jakarta : Gramedia Pustaka Utama

Utami Ulan Dewi, Gusti Ayu Ketut., I Wayan Widiana, I Ketut Dibia. (2016). Analisis Interaksi Guru dan Siswa Dalam Pembelajaran Bahasa Indonesia di Kelas 1 sdn 1 Nawa Kerti. Mimbar PGSD. Vol. 4 No. 1.

Wijana, Nyoman. 2015. Pengaruh Pengintegrasian Pendidikan Karakter Berorientasi Kearifan Lokal Ke Dalam Materi Ajar Mata Kuliah Ilmu Lingkungan Untuk Meningkatkan Soft Skill Mahasiswa Jurusan Pendidikan Biologi Fmipa Undiksha. Jurnal Pendidikan Indonesia. Vol. 4, No.2. 645-657.

Wycoff, Joyce. 2005. Menjadi Super Kreatif Melalui Metode Pemetaan-Pikiran. Terjemahan Rina S. Marzuki. Mind Mapping Your Personal Guide to Exploring Creativity and Problem-Solving. Bandung: Kaifa.

Yoga, D. (2007). Applied Real-Time Mind Map @ Classroom Petunjukn Praktis untuk Menerapkan Kegiatan Belajar Mengajar Berbasis Mind Map. Dipresentasikan di Kalangan Pendidikan 9 Negara di ASIA, 2007.

Yuni Suantini, Ni LP., I Nym Jampel, I Wyn Widiana. (2013). Pengaruh Model Pembelajaran Kooperatif Tipe CIRC Terhadap Pemahaman Konsep IPA Siswa Kelas IV di Gugus II Kecamatan Gerokgak. Mimbar PGSD. Vol. 1 No. 1. 